\title{
Growth Measurments of Male Goat Kids Nourished on Unconventional Rice Straws Ensiled by Corn Steep Liquor and Conventional Rice Straws Ensiled by Urea El-Emam, G. E. ${ }^{1}$; H. R. Behery ${ }^{2}$; Fatma E. Saba ${ }^{2}$; A. L. I. Desoky ${ }^{2}$; A. A. Al-Mwafy ${ }^{3}$ and E. I. Khalifa ${ }^{2}$ \\ ${ }^{1}$ By - Products Utilization Research Department, Animal Production Research Institute, Dokki, Giza, Egypt \\ ${ }^{2}$ Sheep and Goats Research Department, Animal Production Research Institute, Dokki, Giza, Egypt \\ ${ }^{3}$ Veterinary Service Department, Animal Production Research Institute, Dokki, Giza \\ Correspondence author: xyezz@yahoo.com
}

\section{ABSTRACT}

This study aimed to evaluate the effect of dietary types of rice straws ensilaged by corn steep liquor (CSL) or by urea. Fifteen weaning healthy Zaraibi male goats at 120 days of age and weighing $13.65 \pm 0.14 \mathrm{~kg}$ were randomly assigned to three trial (T) groups. T1 was received basal ration contained $60 \%$ concentrate feed mixture (CFM) $+15 \%$ berseem hay (BH) $+25 \%$ dry rice straws (RS). T2 was fed $60 \% \mathrm{CFM}+15 \% \mathrm{BH}+25 \% \mathrm{RS}$ ensilaged by CSL. T3 was fed $60 \% \mathrm{CFM}+15 \% \mathrm{BH}+25 \%$ RS ensilaged by urea. Thus, T1, T2 and T3 were adjusted isocaloric and isonitrogenic and offered up to 150 days as experimental period. The daily dry matter intake (DMI) was determined; by weighed all animals at the beginning and every 15 days during experimental period. Then, growth rate, economic returns, sexual development, digestibility trial and blood metabolites of male goat kids were investigated. Results indicated that ensilage treatment of dry rice straws with CSL or urea has been commonly used for improving $(\mathrm{P}<0.05)$ body weight changes and average daily gain, average DMI and water consumption, efficiency of feed utilization, net economic benefit and digestibility coefficient. Also, kids located in T1 group was delayed in sexual development; while, kids in T2 and T3 were surpassed and had lower $(\mathrm{P}<0.05)$ days of puberty, higher body weight and greater testicular parameters during sexual development. In addition, T1, T2 and T3 diets could be caused stabilization in blood measurements and insignificant values among trial groups. Hence, results indicated that dry rice straws ensiled by CSL was reasonable roughage in promoting feed intakes, animal performance, feed efficiency and economic returns in livestock, which should be considered by local herdsmen to increase their breeding profit.

Keywords: Corn steep liquor, urea, rice straws, ensilage, growth, sexual development, goat kids.

\section{INTRODUCTION}

Dry rice straws are a main agricultural by-product which farmers usually stored for use as ruminant feed in poor area. Rice straws contained low nitrogen, vitamins and minerals which hinder the availability of cellulose to be degraded by rumen microbes and eventually limit the necessary nutrient (Alam et al., 2010). Hence, some studies have been conducted with efforts dedicated towards the most of the potential nutritive value of this agricultural by-product. Hence, ensilation dry straws by urea treatment are a conventional technique for improving the quality of straws to supply protein nutritional needs by increasing the nitrogen contents. Urea as a source of ammonia (NH3) is undesirable method because of NH3 allowed from urea is retained in the ensiled dry straws. Khan et al. (2006) confirmed that usage of urea in ensilage of wheat straw is not perfect to feeding buffaloes because of 30 to $35 \%$ of $\mathrm{NH} 3$ released from urea in treated straws. Moreover, keeping ensiled straws with much nitrogen $(\mathrm{N})$ can held as water-soluble, thus rapidly librated in the rumen and cause nutrient loss at ruminal level. On the other hand, Alam et al. (2016) reported that supplementation moderate of nitrogen $(\mathrm{N})$ to dry straws diets improved feed intake, digestive function and ruminal characteristics in ruminants through influencing rumen microbial growth. Recently, Sheikh et al. (2017) reviewed that using urea to ensile dry rice straws could be resulted in the low nutrient intake (energy and crude protein) because of low dry matter intake leading to low growth rates and poor reproductive and productive performance. To overcome these problems, treated straw residues by appreciable quantum of corn steep liquor (CSL, as one of the by-products of corn industry) may offer a promising protein alternate. It can improve palatability, energy content, biological agents and given feeds high structural carbohydrate and minerals content such as magnesium, phosphorous, calcium, potassium, chloride, sodium, sulfur and myo-inositol phosphates (Xinxin et al.,
2016). Hence, using a mixture of dry rice straws and CSL could increase palatability of diet and acts as readily available source of energy for ruminal microflora for better utilization of ammonical nitrogen for protein synthesis (Li et al., 2013). On the other hand, Qamar et al. (2016) concluded that buffaloes fed diets containing CSL consuming more dry matter intake (DMI), had higher digestibility, better nitrogen balance, produced more milk and lower plasma urea nitrogen (PUN). In addition, Li et al. (2016) found that better fermentation of dry straws ensiling has been successfully applied to succinic acid, cellulolytic enzymes, ethanol and cultivation of microbes such as Enterococcus faecalis RKY1, Lactobacillus rhamnosus CGMCC1466 and Lactobacillus sp. RKY2 for the production of lactic acid. Furthermore, the previous authors defined that CSL in cooperation with other components resulted in $30.4 \%$ higher lactic acid concentration than yeast extract in the Lab. Fermentation. In general, Shahzad et al. (2017) reported that CSL is composed of carbohydrates, peptides, essential amino acids, minerals, vitamins and unidentified organic and inorganic compounds to rice straws ensilage. Hence, lactic acid bacteria in silage are able to ensure fast and vigorous fermentation because of their rapid accumulation of lactic acid and lower $\mathrm{pH}$ values at earlier stages of ensiling (Zhang et al., 2018). So the present study was undertaken to compare the effects of adding either urea or CSL on the nutritive improvement of dry rice straws ensilage and its effect on growth rate, economic returns, measurements of sexual development, digestibility trial and blood metabolites of male goat kids.

\section{MATERIALS AND METHODS}

\section{Description of study site}

This study was carried out in El-Serw Experimental Research Station belongs to Animal Production Research Institute (APRI), Agriculture Research Center, Ministry of Agriculture, Egypt. The experimental study extended from April 2017 to September 2017. 
Treatment of rice straws as ensilage

Ten $\mathrm{cm}$ thick layers of rice straws were made to spray urea solution $(3 \%)$ between these layers by motor to make a heap (up to $500 \mathrm{~kg}$ ). The urea solution heap layers were covered air tightly by plastic sheath and sands which placed above the plastic sheath for assurance of the anaerobic respiration in heap. The same technique was done to prepare heap of $20 \%$ CSL solution. After four weeks, both CSL and urea heaps were opened and samples were taken for analysis. The samples of this fermented ensilage straws were analyzed for dry matter (DM), organic matter $(\mathrm{OM})$, crude protein (CP), crude fibber (CF), either extract (EE), and ash by the methods of AOAC (2007). Nitrogen free extract (NFE) was calculated by difference, whereas metabolic energy (ME) was calculated by Canbolat and Karabulut (2010). At feeding of kids, an amount of the fermented straws by urea or CSL was taken out just sufficient for one day's feeding and the plastic film was covered back to keep the heap locked all time of trial.

\section{Experimental kids}

Fifteen healthy weaning Zaraibi male kids had an initial body weight of $13.65 \mathrm{~kg}$ and their ages were up to 120 days were distributed randomly to three similar groups $(\mathrm{n}=5 /$ group) to research three trial rations as following:

1 -The first trial ration (T1) consisted of $60 \%$ concentrated feed mixture $(\mathrm{CFM})+15 \%$ berseem hay $(\mathrm{BH})$ and $25 \%$ dry rice straws $(\mathrm{RS})$.

2-The second trial ration (T2) included 60\% CFM $+15 \% \mathrm{BH}$ and $25 \%$ dry rice straws ensilaged by CSL solution.

3 - The third trial ration (T3) was $60 \% \mathrm{CFM}+15 \% \mathrm{BH}$ and $25 \%$ dry rice straws ensilaged by urea solution.

All experiential rations were adjusted every fifteen days for isocaloric and isonitrogenic according to NRC (2007) allowances for kids. The chemical analysis of dietary ingredients and experimental rations (T1, T2 and T3) was determined and given in Tables 1 and 2, respectively using AOAC (2007).

Table 1. Chemical analysis of dietary ingredients, \% dry matter basis

\begin{tabular}{lccccc}
\hline \multirow{2}{*}{$\begin{array}{l}\text { Chemical } \\
\text { analysis }\end{array}$} & CFM & BH & RS & $\begin{array}{c}\text { RS* } \\
\text { +CSL }\end{array}$ & $\begin{array}{c}\text { RS** } \\
\text { +urea }\end{array}$ \\
\cline { 2 - 6 } & & & & Dietary ingredients \\
OM & 14.77 & 87.65 & 80.23 & 84.20 & 83.79 \\
CP & 7.40 & 13.10 & 3.08 & 6.07 & 5.06 \\
CF & 29.96 & 36.88 & 31.09 & 35.60 \\
EE & 2.41 & 2.35 & 1.49 & 1.42 & 1.18 \\
NFE & 63.87 & 42.24 & 38.78 & 44.99 & 41.86 \\
Ash & 12.23 & 12.35 & 19.77 & 15.80 & 16.21 \\
ME (k cal/kg DM) 3246.41 & 3153.28 & 3117.763142 .24 & 3122.74 \\
\hline * RS+CSL=rice straws ensilage by con steep liquor. **RS+urea= rice
\end{tabular}

Table 2. Chemical analysis of experimental rations, $\%$ dry matter basis

\begin{tabular}{lccc}
\hline Chemical & \multicolumn{3}{c}{ Experimental rations (\% as DM) } \\
\cline { 2 - 4 } Analysis \% & T1 & T2 & T3 \\
\hline OM & 86.22 & 86.58 & 86.67 \\
CP & 13.33 & 13.43 & 13.40 \\
CF & 39.51 & 37.45 & 40.17 \\
EE & 3.02 & 2.58 & 2.55 \\
NFE & 30.36 & 33.12 & 30.55 \\
Ash & 14.78 & 13.42 & 13.33 \\
*ME(k cal/kg DM) & 3117.12 & 3123.99 & 3112.90 \\
\hline T1=this ration is costed 2497 LE/ton. & & \\
T2=this ration is costed 2537 LE/ ton. & & \\
T3=this ration is costed 2525 LE/ ton.
\end{tabular}

\section{Experimental procedures}

All trial kids in each group were housed in individual $4 \times 5 \mathrm{~m}$ pens to enable studing digestibility trial. The fresh water and mineral licking salt blocks were available ad libitum throughout the experimental period.

\section{Measurements of growth rate}

Body weight changes and average daily gain

All kids were weighed using a digital scale (PN-440 sheep and goat Scale). Body weight (BW) for each kid was recorded fortnightly in the morning at 8.00 a.m before feed was provided. Average daily gain (ADG), for each kid was calculated in middle stage (at 195 days post- weaning) and in late stage (at 270 days post-weaning) of trial by the following formula: $\mathrm{ADG}=$ the final $\mathrm{BW}$ - initial $\mathrm{BW}$ duration of experimental period (75 days of each stage).

\section{Average of feed intake and water consumption}

These measurements were carried out two times throughout the trial period, it's assayed in middle stage (at 195 days post-weaning) and in late stage (at 270 days postweaning) as following: The average feed intake (AFI) was estimated individually for each kid / trial ration (consumed diets throughout 24 hours) by offered a known quantity of ration and recorded the refusal of ration from the previous day in the morning. Water was offered to each kid on a daily basis using bucket full of 5 litter of water placed next to feeding manger box. Average water consumption (AWC) was assessed by measuring the volume of water lost from an identical bucket placed after 24 hours.

\section{Efficiency of feed utilization}

The average daily gains of the animals were estimated in order to determine feed efficiency. The efficiency of feed utilization and live weight gains were calculated as follows: Efficiency of feed utilization = total feed intake $(\mathrm{kg}) /$ live weight gain $(\mathrm{kg})$. Live weight gain $(\mathrm{kg})=$ finished live weight $(\mathrm{kg})$-initial live weight $(\mathrm{kg})$

\section{Net economic benefit (NEB):}

It was determined by the following equation: $\mathrm{NEB}=$ $(\mathrm{G} w \times \mathrm{P} m) \div(\mathrm{T} e \times \mathrm{DC} \times \mathrm{P} d)-1$; where: $G w=$ total live weight gain $(\mathrm{kg}), P m=$ market unit price of live animals (LE), $T e=$ the experiment time (day), $\mathrm{DC}=$ daily consumption $(\mathrm{kg} / \mathrm{d}), P d=$ unit price of given diet (LE). In respect of sell kids as sire for breeding or mutton meat so, the NEB determine after two periods (as 75 or 150 days post-weaning).

Measurements of sexual development

Sexual puberty phases observed for T1, T2 and T3 groups using an oestrus cycle nanny goat for 25 minutes to detect sexual libido of kids. The three sexual puberty phases were discussed as follows: 1: kids showed mounting with desire trembling without penis exposure. 2: kids could display mounting with penis exposure. 3: kids produced first semen ejaculate containing motile sperm. The kids' age, scrotal circumference, testes' volume and testosterone levels were determined at each phase of puberty. The scrotal circumference (SC) obtained using a cloth tape and measured in centimeters $(\mathrm{cm})$ as the largest diameter of scrotum after pushing the testes firmly into the scrotum. The testes volume $(\mathrm{cm} 3)=0.015409 \times \mathrm{SC} 3$ was calculated according to Entwistle (1992).

\section{Digestibility trial}

Each morning after 140 days (post-weaning) of feeding trial, daily total feces excretion per group was collected for seven days. Each day's fecal output of each 
group was weighed and $20 \%$ was sub-sampled and stored frozen at $-20^{\circ} \mathrm{C}$. The daily total fecal excretion per group was used for the determination of digestibility coefficient. Samples of feces were dried at $55^{\circ} \mathrm{C}$ for about $72 \mathrm{hrs}$ in a forced draft oven and ground to pass $1 \mathrm{~mm}$ mesh screen size and used for determination of chemical composition. The crude protein $(\mathrm{CP})$, dry matter (DM) and organic matter (OM) were analyzed according to AOAC (2007). Neutral detergent fibers (NDF) and acid detergent fiber (ADF) were analyzed based on the method of Van Soest and Robertson (1985).

\section{Measurements of blood metabolites}

At the end of trials, three kids from each group were choosing randomly to take blood samples (10 $\mathrm{ml}$ blood/ kid). Blood samples were collected individually in the morning before feeding from the jugular vein into clean tubes. After clotting, blood samples were centrifuged at $3000 \mathrm{rpm}$ for 15 min. Then, blood serum was separated and stored at $-20{ }^{\circ} \mathrm{C}$ until analysis. The concentrations of total protein, triglycerides, cholesterol, albumin, urea, creatinine, and ureic acid as well as activity of aspartate aminotransferase (AST) and alanine aminotransferase (ALT) were determined using commercial kits (Diagnostic system Laboratories, Inc., USA). Statistical analysis

All values collection was expressed as mean \pm SEM (Standard Error of Mean). Statistical evaluation of significant difference between means was performed by one-way analysis of variance (ANOVA) followed by the Duncan post hoc test to determine significant differences in all the parameters among all rations using the SPSS/PC computer program (SPSS, 2013). The significance level considered was $\mathrm{P}<0.05$.

\section{RESULTS AND DISCUSSION}

\section{Measurements of growth performance}

Changing of body weight during trial periods

The changing of body weight of kids as affected by $\mathrm{T} 1, \mathrm{~T} 2$ and $\mathrm{T} 3$ rations during middle or late stages of growth periods are graphed in Figures 1 and 2, respectively. The diagrams have drawn that the positive improvement in body weight of kids were fed T2 compared to T1 and T3 kids throughout extended trial times up to 150 days post-weaning. Hence, modification of feed intake by CSL in T2 ration observed in dairy Zaraibi goats (Khalifa et al., 2013), Zaraibi male goats (Behery et al., 2015), lambs (Azizi-Shotorkhoft et al., 2016), buffaloes (Qamar et al., 2016) and in rabbits (Abdelhamid et al., 2017). The previous authors confirmed that CSL is a goodness source to improve body weight of livestock.

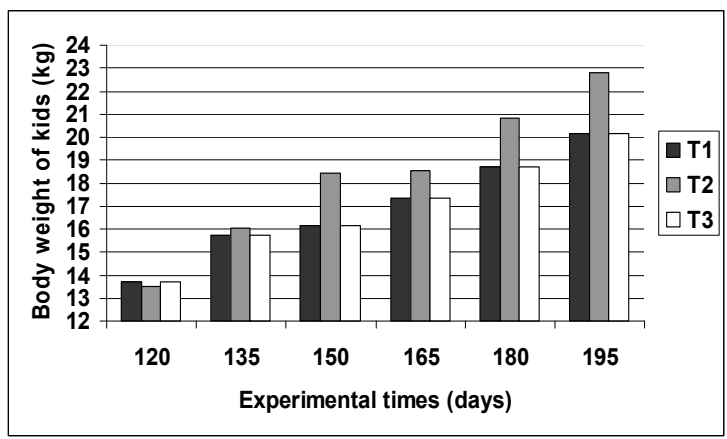

Figure 1. Changes of body weight of kids as affected by $T 1, T 2$ and $T 3$ ration during middle stage of growth rate.

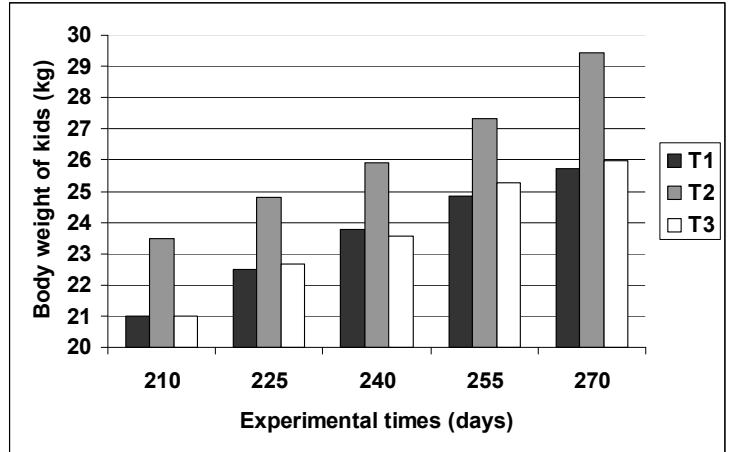

Figure 2. Changes of body weight of kids as affected by $\mathrm{T} 1, \mathrm{~T} 2$ and $\mathrm{T} 3$ ration during late stage of growth rate.

\section{Weight gain and daily weight gain}

The effect of receiving $\mathrm{T} 1, \mathrm{~T} 2$ and $\mathrm{T} 3$ rations on weight gain and daily weight gain of weaning kids during middle stage (at 195 days) and late stage (at 270 days) is presented in Table 3. At the end of the middle feeding trial (at 195 days), kids received T2 rations had higher $(\mathrm{P}<0.05)$ final weight, weight gain and average daily gain compared with kids nourished T1 or T3 rations. Inversely, at the end of the late feeding trial at 270 days, the final body weight showed $(\mathrm{P}<0.05)$ values favored to $\mathrm{T} 2$ kids, but analysis data observed that kids fed $\mathrm{T} 1$ and $\mathrm{T} 3$ rations were not different $(\mathrm{P}>0.05)$ concerning weight gain and average daily weight gain. Thus, the best weight gain and daily weight gain observed in kids fed T2 diet; this could be due to alteration of ration sources such as protein, minerals or energy by using CSL in straws silage. This is in accordance with Behery et al. (2015) who found that final body weight, total weight gain and average daily gain were $26.70 \mathrm{~kg}, 10.85 \mathrm{~kg}$ and $90.42 \mathrm{~g} / \mathrm{d}$ in Zaraibi male kids received CSL compared to $23.70 \mathrm{~kg}$, $7.85 \mathrm{~kg}$ and $65.42 \mathrm{~g} / \mathrm{d}$ in control kids, respectively. On the other hand, Khalifa et al. (2013) reported that rations included CSL were adequate to support live weight and gains by easily soluble carbohydrates for microbial fermentation in the rumen, which improve fermentation which resulting in body weight performance significantly. It is also possible that CSL releases rumen ammonia nitrogen with keto acids (carboxylic acid group and a ketones group) which synchronizes nitrogen and carbon in the rumen towards enhancing microbial proliferation that improves growth (Santos et al., 2012). Recently, Gomaa and El-Badawy (2018) described that improvement of body weight parameters in Zaraibi male by used CSL in ration might have enhanced rumen microbe synthesis and enzyme production which had goodness rumen fermentation and volatile fatty acids production, consequently increasing weight gain and daily weight gain.

\section{Feed intake}

Although the significant $(\mathrm{P}<0.05)$ increases in feed intake by the dietary inclusion of $\mathrm{T} 1$; yet, there were significant $(\mathrm{P}<0.05)$ differences among treatments specially $\mathrm{T} 2$ in average daily gain (Table 3) during experimental intervals. At in silage groups included $\mathrm{T} 2$ and T3 kids, the kids in T3 group consumed the lowest amount of ration, but its average daily gain (ADG) was lower than $\mathrm{T} 2$ ration. This may be related to that urea was used to make straws silage in T3 diet which had less palatability than T2 during growth periods. Analogous findings were 
observed by Qamar et al. (2015) who indicated that improved feed intake and ruminal fermentation in animals fed diets containing CSL may be supplied minerals, peptides and amino acids when compared to those fed diet containing urea. Also, these authors registered that improved digestibility of acid detergent fiber (ADF) and neutral detergent fiber (NDF) in animals fed CSL diets might be attributed to control feed intake by cellulytic and proteolysis activities in rumen. In addition, Behery et al. (2015) found that kids fed ration included CSL consumed lower ration $(1105.75 \mathrm{~g})$ than ration without CSL (1166.51g) during growth period of Zaraibi kids extended to 120 days. Furthermore, Azizi-Shotorkhoft et al. (2016) found that when different rates of CSL up to 36, 72, 108 or $143 \mathrm{~g} / \mathrm{kg} \mathrm{DM}$ were substituted for urea in diets of lambs, the feed intakes of DM, CP, NDF and ADF were linearly increased.

\section{Water consumption}

It takes mean range from 820 to $1350 \mathrm{ml} /$ head /day during middle and late of the experimental periods. Kids in $\mathrm{T} 2$ could be achieved lower $(\mathrm{P}>0.05)$ consumption of water than kids in T1 and T3 in middle and late stage of trial (Table $3)$. Hence, the water consumption increased within advanced kids' age (Abdelhamid et al., 2017) and within changing in environmental conditions (Ahlberg et al., 2018). Also, the lowest water consumption with ration containing CSL may be related to available of energy source as given by Barreto et al. (2012) who displayed that goats fed diet of high energy had significant decrease in consumption of water compared to those fed a diet of low energy. In addition, Behery et al. (2015) found the most daily water intake in growing kids fed rations free of CSL $(3150.00 \mathrm{ml} / \mathrm{head} /$ day $)$ compared to $2321.80 \mathrm{ml} /$ head/day when ration contained CSL.

\section{Efficiency of feed utilization}

Actually, feed efficiency is an important index reflecting digestion and absorption efficiency of a given dietary. In this study, feed efficiency of kids received $\mathrm{T} 2$ and $\mathrm{T} 3$ rations had a relative better $(\mathrm{P}>0.05)$ efficiency level during two stages of the experiment (Table 3). T1 ration was the least efficient in feed conversion among two kids groups given either T2 or T3 diets. Hence, CSL dietary which has higher CP level was better in feed efficiency in kids. There was a similar trend observed by Behery et al. (2015) who fond that feed efficiency in male Zaraibi goats was significantly better when ration contained CSL (12.23) than (17.83) in ration without CSL. Azizi-Shotorkhoft et al. (2016) noticed that variation in feed efficiency among the treatments of lambs was related to the parallel alterations occurred in both DMI and ADG as dietary rates of CSL diet. Besides, $\mathrm{Xu}$ et al. (2017) confirmed that diet could be increased rumen microbial activity, maintaining normal fermentation, digestion, absorption and metabolic activities, which resulting in better growth performance and feed efficiency.

\section{Net economic benefit (NEB)}

The NEB benefit was possibly attributed to different growth performance of kids fed experimental diets (Table 3). Kids were received $\mathrm{T} 2$ and $\mathrm{T} 3$ shared the highest $(\mathrm{P}<0.05)$ NEB compared to those fed $\mathrm{T} 1$ ration through stages of trial. According to Behery et al. (2015), they found that better protein in diet contained CSL had economical efficiency up to $151.44 \%$ than $110.68 \%$ in control diet nourished to Zaraibi male kids. On the other hand, Abdelhamid et al. (2017) showed that diet supplemented with CSL at 10\% achieved economic efficiency up to 20.07 compared to 17.74 in control rabbit. Hence, diets with moderate $\mathrm{CP}$ could be shared a reasonable to NEB was expected (Xu et al., 2017).

Table 3. The effect of $\mathrm{T} 1, \mathrm{~T} 2$ and $\mathrm{T} 3$ rations on growth parameters during middle or late stages of research

\begin{tabular}{|c|c|c|c|}
\hline \multirow{2}{*}{ Specification } & \multicolumn{3}{|c|}{ Experimental rations } \\
\hline & T1 & $\mathbf{T 2}$ & T3 \\
\hline \multicolumn{4}{|c|}{ Middle stage 120 to 195 days } \\
\hline Initial body weight (kg) & $13.74 \pm 0.23$ & $13.50 \pm 0.07$ & $13.70 \pm 0.34$ \\
\hline Final body weight $(\mathrm{kg})$ & $20.16 \pm 0.81^{b}$ & $22.82 \pm 0.58^{\mathrm{a}}$ & $20.16 \pm 0.82^{b}$ \\
\hline Weight gain $(\mathrm{kg})$ & $6.42 \pm 0.62^{\mathrm{b}}$ & $9.32 \pm 0.59^{\mathrm{a}}$ & $6.46 \pm 0.53^{\mathrm{b}}$ \\
\hline Average daily weight gain (g/d) & $85.60 \pm 8.29^{b}$ & $124.26 \pm 7.97^{\mathrm{a}}$ & $86.13 \pm 7.10^{\mathrm{b}}$ \\
\hline Ration consumption $(\mathrm{g} / \mathrm{d})$ & $806.40 \pm 32.44^{\mathrm{a}}$ & $684.60 \pm 17.35^{\mathrm{b}}$ & $604.80 \pm 24.33^{\mathrm{c}}$ \\
\hline Total ration consumption $(\mathrm{kg})$ & $60.48 \pm 2.43^{\mathrm{a}}$ & $51.35 \pm 1.30^{\mathrm{b}}$ & $45.36 \pm 1.82^{\mathrm{c}}$ \\
\hline Efficiency of feed utilization & $9.64 \pm 0.00^{\mathrm{a}}$ & $5.57 \pm 0.00^{c}$ & $7.12 \pm 0.00^{b}$ \\
\hline *Net economic benefit (NEB) & $2.13 \pm 0.00^{\mathrm{b}}$ & $4.85 \pm 0.00^{\mathrm{a}}$ & $4.60 \pm 0.00^{\mathrm{a}}$ \\
\hline Water consumption (ml/animal) & $840.00 \pm 88.60$ & $820.00 \pm 84.26$ & $830.00 \pm 99.75$ \\
\hline \multicolumn{4}{|c|}{ Late stage 195 to 270 days } \\
\hline Initial body weight (kg) & $21.00 \pm 0.80^{\mathrm{b}}$ & $23.48 \pm 0.77^{\mathrm{a}}$ & $21.20 \pm 0.71^{\mathrm{ab}}$ \\
\hline Final body weight (kg) & $25.72 \pm 0.46^{b}$ & $29.42 \pm 0.64^{\mathrm{a}}$ & $25.98 \pm 0.34^{\mathrm{b}}$ \\
\hline Weight gain $(\mathrm{kg})$ & $4.72 \pm 0.49$ & $5.94 \pm 0.34$ & $4.78 \pm 0.38$ \\
\hline Average daily weight gain $(\mathrm{g} / \mathrm{d})$ & $62.93 \pm 6.49^{b}$ & $79.20 \pm 4.55^{\mathrm{a}}$ & $63.73 \pm 5.08^{\mathrm{b}}$ \\
\hline Ration consumption $(\mathrm{g} / \mathrm{d})$ & $900.20 \pm 16.01^{\mathrm{a}}$ & $882.60 \pm 19.05^{b}$ & $779.40 \pm 10.19^{b}$ \\
\hline Total ration consumption $(\mathrm{kg})$ & $67.52 \pm 1.20^{\mathrm{a}}$ & $66.19 \pm 1.43^{\mathrm{b}}$ & $58.46 \pm 0.76^{\mathrm{b}}$ \\
\hline Efficiency of feed utilization & $14.96 \pm 1.67^{\mathrm{a}}$ & $11.28 \pm 0.00^{b}$ & $12.60 \pm 1.19^{\mathrm{b}}$ \\
\hline *Net economic benefit (NEB) & $0.001 \pm 0.00^{\mathrm{b}}$ & $1.28 \pm 0.00^{\mathrm{a}}$ & $1.25 \pm 0.00^{\mathrm{a}}$ \\
\hline Water consumption (m1/animal) & $1350 \pm 15.81$ & $1330 \pm 33.17$ & $1340 \pm 40.62$ \\
\hline
\end{tabular}

$\mathrm{A}, \mathrm{b}$ and c: Means with different superscripts in the same row are significantly different at $(\mathrm{P}<0.05)$.

* Market unit price of live animals equal 55 LE.

\section{Measurements of sexual development}

The results found that male kids during sexual development varied $(\mathrm{P}<0.05)$ among three phases (first, second and third) of sexual puberty. Kids in T1 was delayed in sexual development while, kids in $\mathrm{T} 2$ and $\mathrm{T} 3$ were surpassed and had lower $(\mathrm{P}<0.05)$ days of puberty, higher 
body weight and greater testicular parameters during 253 days of sexual development age (Table 4). The improvement of sexual puberty in kids fed $\mathrm{T} 2$ ration may be related to the different components in CSL such as minerals, vitamins, carbohydrates which had positive effect on sexual maturation of kids post-weaning. Similar reports were made by Behery et al. (2015) who working with Zaraibi male kids, the authors observed occurrence of puberty at about the 216 days postweaning when kids received ration contain CSL compared to 245 days in control ration without CSL. Actually, there are positive relationships between plane of nutrition and gonadotropin secretion in male ruminants. According to
Mohamed and Abdelatif (2010), they suggested that males received the best plane of nutrition could be resulted in increasing sexual hormones. Also, these authors showed that testicular hormones play an important role in penis detachment and increasing in testis scrotal circumference. Amelioration source ingredients of diets such as protein and energy play a major role in controlling many reproduction aspects including hormone production, gametogenesis and maturation sexual phases (Panzuti et al., 2018A). Similarly, Panzuti et al. (2018B) found that amendment rations postweaning is supplying enough DM to achieve a compensatory growth which resulting in sexual maturity.

\section{Table 4. Mean $\pm \mathrm{SE}$ of sexual development of male kids nourished different rations}

\begin{tabular}{|c|c|c|c|}
\hline \multirow{2}{*}{$\begin{array}{l}\text { Sexual } \\
\text { devolvement }\end{array}$} & \multicolumn{3}{|c|}{ Different trial rations } \\
\hline & T1 & $\mathbf{T 2}$ & T3 \\
\hline \multicolumn{4}{|c|}{ First phase: mating with desire trembling without penis exposure } \\
\hline Age, days & $189.80 \pm 1.85^{\mathrm{a}}$ & $160.60 \pm 2.06^{\mathrm{c}}$ & $179.40 \pm 2.25^{\mathrm{b}}$ \\
\hline Body weight, $\mathrm{kg}$ & $19.88 \pm 0.59^{\mathrm{b}}$ & $21.56 \pm 0.26^{\mathrm{a}}$ & $20.08 \pm 0.48^{\mathrm{b}}$ \\
\hline Scrotal circumference, $\mathrm{Cm}$ & $14.48 \pm 0.35^{\mathrm{c}}$ & $19.24 \pm 0.52^{\mathrm{a}}$ & $17.48 \pm 0.43^{b}$ \\
\hline Testicular volume, $\mathrm{Cm}^{3}$ & $47.11 \pm 3.41^{\mathrm{c}}$ & $110.70 \pm 8.81^{\text {a }}$ & $82.89 \pm 6.14^{\mathrm{b}}$ \\
\hline \multicolumn{4}{|c|}{ Second phase: mating with penis exposure } \\
\hline Age, days & $219.80 \pm 2.43^{\mathrm{a}}$ & $184.20 \pm 3.17^{\mathrm{c}}$ & $202.80 \pm 2.85^{b}$ \\
\hline Body weight, $\mathrm{kg}$ & $22.08 \pm 0.36^{\mathrm{b}}$ & $23.76 \pm 0.28^{\mathrm{a}}$ & $23.52 \pm 0.33^{\mathrm{a}}$ \\
\hline Scrotal circumference, $\mathrm{Cm}$ & $17.44 \pm 0.41^{\mathrm{c}}$ & $22.26 \pm 0.54^{\mathrm{a}}$ & $19.80 \pm 0.13^{\mathrm{b}}$ \\
\hline Testicular volume, $\mathrm{Cm}^{3}$ & $82.27 \pm 5.69^{\mathrm{c}}$ & $171.12 \pm 12.36^{\mathrm{a}}$ & $119.67 \pm 2.36^{\mathrm{b}}$ \\
\hline \multicolumn{4}{|c|}{ Third phase: mating with first semen ejaculate containing motile sperm } \\
\hline Age, days & $253.20 \pm 2.84^{\mathrm{a}}$ & $230.80 \pm 1.36^{\mathrm{c}}$ & $242.60 \pm 2.99^{b}$ \\
\hline Body weight, $\mathrm{kg}$ & $25.04 \pm 0.25^{\mathrm{b}}$ & $26.32 \pm 0.16^{\mathrm{a}}$ & $25.88 \pm 0.15^{\mathrm{a}}$ \\
\hline Scrotal circumference, $\mathrm{Cm}$ & $20.48 \pm 0.57^{\mathrm{c}}$ & $25.28 \pm 0.31^{\mathrm{a}}$ & $23.10 \pm 0.30^{\mathrm{b}}$ \\
\hline Testicular volume, $\mathrm{Cm}^{3}$ & $133.56 \pm 1.07^{\mathrm{c}}$ & $249.38 \pm 9.05^{\mathrm{a}}$ & $190.31 \pm 7.25^{b}$ \\
\hline
\end{tabular}

$\mathrm{A}, \mathrm{b}$ and c: Means with different superscripts in the same row are significantly different at $(\mathrm{P}<0.05)$.

\section{Digestibility trial}

There was an improvement $(\mathrm{P}<0.05)$ of $\mathrm{DM}$, OM, $\mathrm{CP}, \mathrm{NDF}$ and ADF for the T2 and T3 kids compared to kids fed T1 diet (Table 5). Similar to the current study, ensiled rice straws with CSL (Qamar et al., 2016) or urea (Assefa et al., 2015) improved of DM of the diet compared to the dry rice straws alone. The improvement of $\mathrm{CP}$ digestibility for $\mathrm{T} 2$ or T3 kids due to higher intake of dietary protein which associated with higher $\mathrm{CP}$ intake. This finding might be probably due to increase rate of ruminal NH3 formation (Wanapat et al., 2013). In addition, Qamar et al. (2016) showed that higher CP located in CSL could enhance ruminal fermentation through increased microbial enzyme production. Also these authors proposed that increasing of DM and NDF digestibility fed diets containing CSL may be due to rapidly fermentable nature. The CSL has sufficient nitrogen availability in the rumen compared to control diet or containing urea (Qamar et al., 2015). The lowest nutrient digestibility in T1 kids attributed to the high level of combustion of NDF and ADF compared to T2 or T3 kids (Assefa et al., 2015) revealed to lower CP content of the dry rice straws as than ensilage of rice straws by CSL or urea.

Table 5. The effect of $T 1, T 2$ and $T 3$ rations on digestibility coefficient $(\%)$

\begin{tabular}{lccc}
\hline \multirow{2}{*}{ Nutrients } & \multicolumn{3}{c}{ Experimental rations } \\
\cline { 2 - 4 } & $\mathbf{T 1}$ & $\mathbf{T 2}$ & $\mathbf{T 3}$ \\
\hline Dry matter & $59.12 \pm 6.32^{\mathrm{b}}$ & $73.23 \pm 4.55^{\mathrm{a}}$ & $72.24 \pm 4.25^{\mathrm{a}}$ \\
Organic matter & $65.25 \pm 4.58^{\mathrm{b}}$ & $77.14 \pm 4.14^{\mathrm{a}}$ & $76.32 \pm 4.13^{\mathrm{a}}$ \\
Crude protein & $44.53 \pm 3.54^{\mathrm{b}}$ & $67.49 \pm 3.92^{\mathrm{a}}$ & $65.70 \pm 4.42^{\mathrm{a}}$ \\
Neutral detergent fiber & $68.34 \pm 5.23^{\mathrm{b}}$ & $75.74 \pm 5.11^{\mathrm{a}}$ & $78.45 \pm 4.61^{\mathrm{a}}$ \\
Acid detergent fiber & $48.78 \pm 4.51^{\mathrm{b}}$ & $65.68 \pm 5.22^{\mathrm{a}}$ & $64.89 \pm 5.62^{\mathrm{a}}$ \\
\hline
\end{tabular}

$A$ and b: Means with different superscripts in the same row are significantly different at $(\mathrm{P}<\mathbf{0 . 0 5})$.

\section{Blood metabolic}

Data in Table (6) illustrated the effect of T1, T2 and $\mathrm{T} 3$ ration on some blood metabolites. Results showed that the blood metabolites of all kids were non-significantly affected by the dietary treatments. However, kids in T1 ration showed lower $(\mathrm{P}>0.05)$ values of blood parameters than those on $\mathrm{T} 2$ and $\mathrm{T} 3$ rations. These increases in total protein in $\mathrm{T} 2$ and $\mathrm{T} 3$ kids may be due to the presence of CSL protein and amino acid in urea that might be let to improvement the digestibility of $\mathrm{CP}$ that considering the main resin for increases the of total protein blood concentration. In like manner, AziziShotorkhoft et al. (2016) recorded that blood total protein concentration was $6.71,7.31$ and $7.14 \mathrm{~g} / \mathrm{dl}$ and albumin was $2.72,2.63$ and $2.79 \mathrm{~g} / \mathrm{dl}$ when lambs received rations contained 0,50 and $100 \mathrm{~g} / \mathrm{kg}$ of CSL supplemented to dry matter, respectively. On the other hand, Abdelhamid et al. (2017) reported that rabbit rations contained CSL could increased total protein and albumin. Enhance of total protein could relate to available carbohydrate source, impaired $\mathrm{N}$ utilization by rumen microbes thus, both $\mathrm{N}$ utilization as well as digestibility of $\mathrm{CP}$ were better as a result in serum protein (Mudgal et al., 2018). The non-significant affected of T1, T2 and T3 ration on triglycerides and cholesterol were in agreement with those results observed in Zaraibi kids (Behery et al. (2015), in lambs (Azizi-Shotorkhoft et al., 2016) and in rabbit (Abdelhamid et al., 2017) nourished CSL in rations. Noticeably, urea and creatinine concentrations are an indicator to regular filtration in the kidney and also there were not a catabolism situation consequently, being in a good nutritional condition. Hence in this investigation, the levels of creatinine and urea were not affected significantly by 
treatments. Similar finding was also reported by AziziShotorkhoft et al. (2016) who noticed that creatinine level increased without significance up to $1.31,1.37$ and 1.45 $\mathrm{mg} / \mathrm{dl}$ and urea levels up to $8.24,8.71$ and $9.89 \mathrm{mg} / \mathrm{dl}$ in blood of lambs fed CSL at 0,50 and $100 \mathrm{~g} / \mathrm{kg}$, respectively. In addition, the best kidneys function in CSL kids may be due to the antioxidant nature of vitamin $\mathrm{E}$ which regulating the antioxidative defense enzyme system in the kidney tissues (Khalifa et al., 2013). Indeed, aminotransferase enzymes (ALT and AST) play an important role in intermediate metabolic processes as it provides a mean for the synthesis and degradation of amino acid in cells. The liver cell damage due to increase serum activity of both enzymes (ALT and AST), but ALT enzyme is more specific for liver damage than AST enzyme. In the current study, the blood serum of ALT and AST enzymes activity in T1, T2 and T3 did not significantly alter this refers safety physiological normal ranges for trial kids. Decidedly, CSL contains substances could protect liver from oxidative damage and some powerful antioxidants which may prevent free radical formation that already formed (Khalifa et al., 2013). On the other hand, Abdelhamid et al. (2017) found that rabbit rations supplemented with CSL had higher AST and lower ALT enzymes than rabbit ration without CSL.

Table 6. The effect of T1, T2 and T3 rations on blood metabolites at end stages of the experiment

\begin{tabular}{lccc}
\hline \multirow{2}{*}{$\begin{array}{l}\text { Serum } \\
\text { metabolites }\end{array}$} & \multicolumn{3}{c}{ Experimental rations } \\
\cline { 2 - 4 } Total protein, g/dI & $5.77 \pm 0.22$ & $5.99 \pm 0.45$ & $6.29 \pm 0.55$ \\
Albumin, g/dI & $3.65 \pm 0.58$ & $3.82 \pm 0.44$ & $3.76 \pm 0.57$ \\
Cholesterol, mg/dI & $68.00 \pm 14.74$ & $58.88 \pm 5.29$ & $64.67 \pm 7.42$ \\
Triglyceride, mg/dI & $14.67 \pm 4.02$ & $15.11 \pm 4.41$ & $16.67 \pm 2.31$ \\
Urea, mg/dI & $76.03 \pm 9.89$ & $78.18 \pm 3.72$ & $77.34 \pm 5.55$ \\
Uric Acid, mg/dI & $3.22 \pm 0.32$ & $3.33 \pm 0.08$ & $3.35 \pm 0.34$ \\
Creatinine, mg/dI & $1.56 \pm 0.45$ & $1.66 \pm 0.54$ & $1.71 \pm 0.58$ \\
AST, U/I & $30.33 \pm 4.88$ & $31.00 \pm 3.61$ & $31.67 \pm 5.11$ \\
ALT, U/I & $5.33 \pm 1.33$ & $5.37 \pm 2.67$ & $5.42 \pm 2.00$ \\
\hline
\end{tabular}

\section{CONCLUSION}

The CSL and urea ensilaged rice straw could improve nutritive value of dry rice straw, increase all growth measurements, improve sexual development, stabilize nutrient digestibility and balance blood metabolites. In addition, this study suggested that CSL ensiled dry rice straw can be used as a good and healthy roughage source for livestock within the lowest cost, as well as its applicability for use under practical farm conditions.

\section{REFERENCES}

Abdelhamid, A. M., H. R. Behery and Sahar R. M. Hammoudah (2017). Possible utilization of corn steep liquor (CSL) in rabbits' diet. International Journal Current Research Bioscience Plant Biology, 4 (11): 57-69.

Ahlberg, C. M., K. Allwardt, A. Broocks, K. Bruno, L. McPhillips, A. Taylor, C. R. Krehbiel, M. S. CalvoLorenzo, C. J. Richards, S. E. Place, U. DeSilva, D. L. VanOverbeke, R. G. Mateescu, L. A. Kuehn, R. L. Weaber, J. M. Bormann and M. M. Rolf. (2018). Environmental effects on water intake and water intake prediction in growing beef cattle. Journal Animal Science, 96: 4368-4384.
Alam, M. K., Y. Ogata, Y. Sako, M. Al-Mamun and H. Sano. (2010). Intermediary metabolism of plasma acetic acid, glucose and protein in sheep fed a rice straw-based diet. Asian Australas Journal Animal Science, 23: 1333-1339.

Alam, M. K., Y. Ogata, Y. Sato and H. San. (2016). Effects of rice straw supplemented with urea and molasses on intermediary metabolism of plasma glucose and leucine in sheep. Asian-Australas Journal Animal Science, 29(4): 523-529.

AOAC (2007). Association of Official Analytical Chemists. Official Methods of Analysis. $19^{\text {th }}$ Edition. Washington, DC: AOAC. USA.

Assefa, F., M. Urge and G. Animut (2015). Growth performance of Adilo sheep fed urea treated wheat straw supplemented with enset(Enseteventricosum), atella and their mixtures. African Journal Agriculture Research, 10 (24): 2444-2452.

Azizi-Shotorkhoft, A., A. Sharifi, D. Mirmohammadi, H. Baluch-Gharaei and J. Rezaei (2016). Effects of feeding different levels of corn steep liquor on the performance of fattening lambs. Journal Animal Physiology Animal Nutrition, 100 (1):109-117.

Barreto, L. M. G., A. N. Medeiros, Â. M. V. Batista, G. G. L. Araújo, D. A. Furtado, A. C. C. Lisboa, J. L. A Paulo and A. R. Alves, (2012). Growth performance of native goats fed diets containing different levels of energy. Revista Brasileira de Zootecnia, 41 (3): 675682.

Behery, H. R., Khalifa, E. I. Hanan, A. M. Hassanien and Amal A. Fayed (2015). Nourishment of conventional and non-conventional energy and its impact on productive and reproductive performance of Zaraibi male goats. Egyptian Journal of Nutrition and Feeding. 12 (2): 65-90.

Canbolat, Ö. and A. Karabulut (2010). Effect of urea and oregano oil supplementation on growth performance and carcass characteristics of lamb fed diets containing different amounts of energy and protein. Turk. J. Vet. Anim. Sci., 34 (2): 119-128.

Entwistle, K. (1992). A brief update on male reproductive physiology. In: Bull Fertility. R. G. Holroyd, Ed. Queensland Gov., Brisbane. P:1.

Gomaa, A. A. A. I. and A. A. El-Badawy (2018). Effect of feeding Zaraibi male goats on rations containing different levels of corn steep liquor, as a source of protein, on growth performance and carcass quality. Egyptian Journal of Sheep and Goat Sciences, 13 (1): 19-31.

Khalifa, E. I., H. R. Behery, Y. H. Hafez, A. A. Mahrous, Amal, A. Fayed and Hanan, A. M. Hassanien. (2013). Supplementing non-conventional energy sources to rations for improving production and reproduction performances of dairy Zaraibi nanny goats. Egyptian Journal of Sheep \& Goat Sciences, 8 (2): 69-83.

Khan, M. A., M. Sarwar, M. Nisa, S. A. Bhatti, Z. Iqbal, W. S. Lee, H. J. Lee, H. S. Kim and K. S. Ki. (2006). Feeding value of urea treated wheat straw ensiled with or without acidified molasses in Nili-Ravi buffaloes. Journal Animal Science, 19: 645-650.

Li, X., W. Xu, J. Yang, H. Zhao, C. Pan and X. Ding. (2016). Effects of applying lactic acid bacteria to the fermentation on a mixture of corn steep liquor and air-dried rice straw. Animal Nutrition, 3 (2): 229-233. 
Li, X., Y. G. Zhang, W. W. Zhang, N. Zhang, K. Y. Liu and C. L. Li. (2013). Effects of mixing corn steep liquor with dry rice straw in different proportions on fermentation quality and nutrient composition of yellow rice straw silage feed. Chinese Journal Animal Science, 25 (11): 2682-2688.

Mohamed, S. S. and A. M. Abdelatif (2010). Effects of level of feeding and season on thermoregulation and semen characteristics in Desert Rams (Ovis aries). Global veterinaria. 4 (3): 207-215.

Mudgal, V., M. K. Mehta and A. S. Rane (2018). Lentil straws (lens culinaris): An alteration and nutritious feed resource for kid. Animal Nutrition, 4 (4): 417 421.

NRC (2007). Nutrient Requirements of Small Ruminants: sheep, goats, cervids, and New World camelids. National Research Council of the National Academies, National Academies Press, Washington, D.C., U.S.A.

Panzuti, C., C. Duvaux-Ponter and F. Dessauge $\left(2018^{\mathrm{A}}\right)$. High feeding level after early weaning had no impact on subsequent milk production in Alpine goats. Journal of Applied Animal Research, 46 (1): 1344 1351.

Panzuti, C., G. Mandrile, C. Duvaux-Ponter, F. Dessauge. $\left(2018^{\mathrm{a}}\right)$. Early weaning and high feeding level in postweaning period did not impact milk production in Alpine dairy goats. Journal Dairy Research, 1- 4.

Qamar, M. S., M. Nisa, M. Sarwar, Z. Rahman and T. Huma. (2016). Substituting corn steep liquor with urea as nitrogen equivalence on nutrients intake, digestibility, blood biochemistry and milk composition in early lactating Nili-Ravi buffaloes. The Journal of Animal \& Plant Sciences, 26 (5): 1212-1217.

Qamar, M. S., M. Un-Nisa, M. Sarwar and Z. Ur-Rahman (2015). Influence of varying levels of corn steep liquor on nutrients intake, digestibility and growth response in growing buffalo calves. Journal of Animal and Poultry Sciences, 4 (3): 39-48.

Santos, V. L. F., M. A. Ferreira, A. Guim, F. M. Silva, S. A. Urbano, and E. C. Silva (2012). Protein sources for crossbred dairy cows in the semiarid. Revista Brasileira de Zootecnia, 41(10): 2272-2278.
Shahzad, F., M. Abdullah, A. S. Chaudhry, A. S. Hashmi, J. A. Bhatti, M. A. Jabbar, H. M. Ali, T. Rehman, F. Ali, M. M. K. Sattar, F. Ahmed and I. Irshad (2017). Addition of molasses, corn steep liquor, and rice polish as economical sources to enhance the fungal biomass production of wheat straw by Arachniotus sp. Turkish Journal of Veterinary and Animal Sciences, 41: 332-336.

Sheikh, G. G., A. M. Ganai, F. A. Sheikh, S. A. Bhat, D. Masood, S. Mir, I. Ahmad and M. A. Bhat. (2017). Effect of feeding urea molasses treated rice straw along with fibrocystic enzymes on the performance of Corriedale Sheep. Journal of Entomology and Zoology Studies, 5 (6): 2626-2630.

SPSS (2013). Statistical package for social sciences, IBM $^{\mathbb{B}}$ SPSS Statistics Data Editor 22.0 License Authorization Wizard, Chicago, USA.

Van Soest, P. J. and J. B. Robertson (1985). Analysis of forages and fibrous feeds. A laboratory manual for animal science, Vol. 613. Cornell University, Ithaca, New York.

Wanapat, M., S. Kang, N. Hankla and K. Phesatcha (2013). Effect of rice straw treatment on feed intake, rumen fermentation and milk production in lactating dairy cows. African Journal Agriculture Research, 8 (17):1677-1687.

Xinxin, L. i., X. U.Wenbin, J. Yang, H. Zhao and H. Xin (2016). Effect of different levels of corn steep liquor addition on fermentation characteristics and aerobic stability of fresh rice straw silage. Animal Nutrition, 2: 345-350.

Xu, T., S. Xu, L. Hu, N. Zhao, Z. Liu and L. Ma (2017). Effect of dietary types on feed intakes, growth performance and economic benefit in Tibetan sheep and Yaks on the Qinghai-Tibet Plateau during cold season. PLoS ONE, 12 (1): 1-15.

Zhang, M., X. Wang, M. Cui, Y. Wang, Z. Jiao and Z. Tan. (2018). Ensilage of oats and wheatgrass under natural alpine climatic conditions by indigenous lactic acid bacteria species isolated from high-cold areas. PLoS ONE, 13 (2): 1-15.

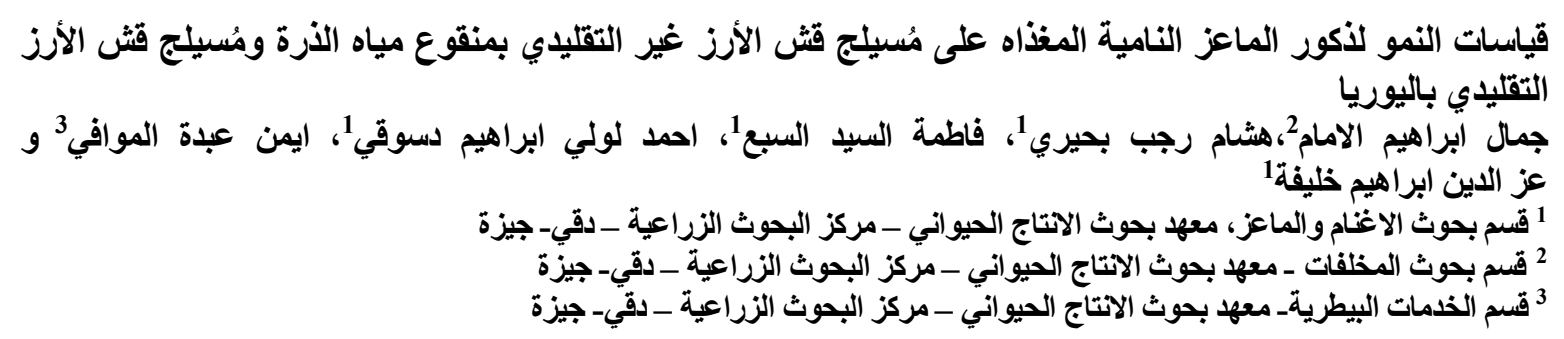

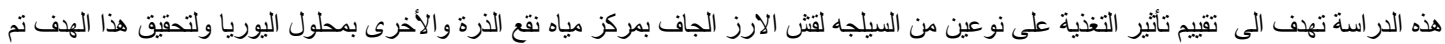

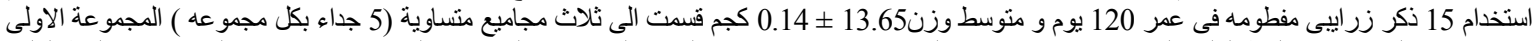

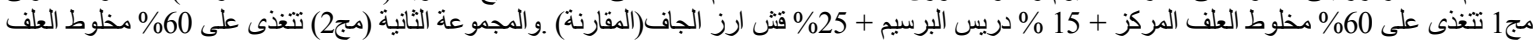

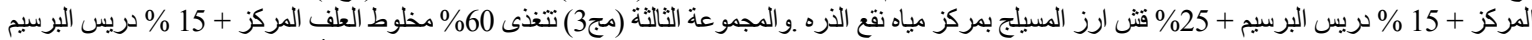

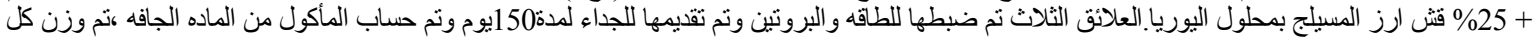

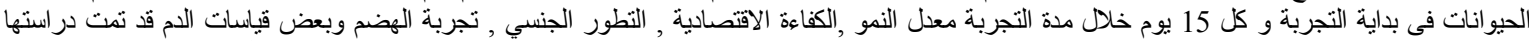

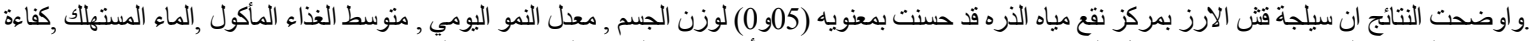

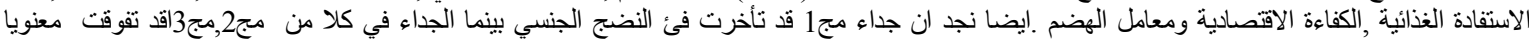

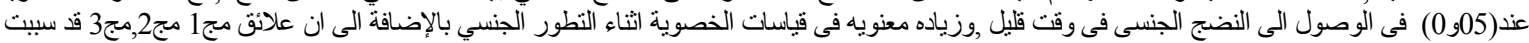

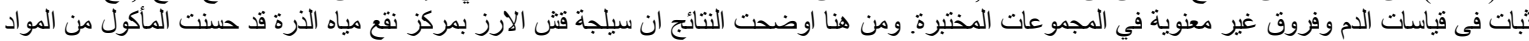

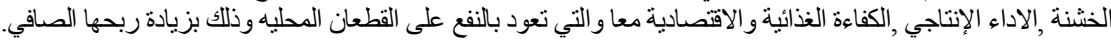

